\title{
1
}

\section{Understanding Values Work in Organisations and Leadership}

\section{Harald Askeland, Gry Espedal, Beate Jelstad Løvaas and Stephen Sirris}

Values are fundamental to organisations. Considered key determinants of attitudes, work behaviour and decision-making, values in organisations have emerged as a topic of growing interest among organisational scholars and practitioners. By signifying what is desirable or appropriate, values guide the choice of action. However, they do not offer precise or standardised prescriptions of actions. Organisations focusing on values work are in a better position to improve their practices and quality of services. We believe that values work serves to bridge everyday practices with the organisational purpose.

\footnotetext{
H. Askeland ( $\varangle) \cdot$ G. Espedal · B. Jelstad Løvaas · S. Sirris VID Specialized University, Oslo, Norway e-mail: harald.askeland@vid.no

G. Espedal e-mail: gry.espedal@vid.no

B. Jelstad Løvaas

e-mail: beate.jelstad.lovaas@vid.no

S. Sirris

e-mail: Stephen.Sirris@vid.no 
Work on values in organisations also assumes significance in the light of the contexts in which organisations operate. Organisations are part of a broad and heterogeneous institutional environment. Market, regulations and laws establish a context of challenges and difficulties, often forcing organisations to juggle between disparate demands, which result in persistent and deep-rooted tensions. How do, for instance, organisations pursue productivity while keeping their soul intact and delivering services true to their original purpose? Values come into play in such situations of institutional pluralism (Kraatz \& Block, 2008) or institutional complexity (Greenwood, Raynard, Kodeih, Micelotta, \& Lounsbury, 2011), and they may have different roles. Essentially, working with values in workplaces involves probing why people work and behave the way they do. We, therefore, address the following question: In a complex and plural institutional context, how do leaders and members perform values work?

By placing values work at the heart of what the actors do, the chapters in this book manifest a performative and processual practice.

\section{Purpose and Focus of the Book}

The purpose of this book is to provide new insights into how work on values is performed in organisations. The book is an edited collection of theoretical and empirical chapters that report cases from various organisations and institutional contexts in Scandinavia, Europe and Africa. We give special attention to values-salient organisations, particularly public and civic welfare organisations, as much of their interactions are characterised by competing demands and divergent value orientations, and their practices are conceived as moral work (Hasenfeld, 1983). We have focused on studying values-salient organisations because they represent an 'extreme' scenario in our study area.

Whereas previous literature on values has focused on cultural and cognitive perspectives, the starting point of this book is a practice perspective that analyses what is being done by whom and how, in relation to values. We especially identify and emphasise micro-processes in complex and challenging organisational situations_an area where the literature 
on institutions and institutional theories is relatively silent. By adopting a practice perspective and focusing on micro-processes, we fill a gap and call for research on institutional theories (Hampel, Lawrence, Tracey,Greenwood, \& Oliver, 2017; Micelotta, Lounsbury, \& Greenwood, 2017). Using in-depth studies on institutional leadership and practices of values work in organisations, this book applies different theoretical lenses within the umbrella of institutional theories combined with micro-level perspectives and practice-based approaches.

\section{Introducing Values and Values Work}

Values are intractably connected to norms and morals: they signify worth, preferences and priorities and separate the desirable from the undesirable. The question of realising the 'good' is an existential theme that may align with the telos and overall goals inherent to practices. For several case organisations discussed in this volume, realising the good is a fundamental theme because they identify as faith-based (Askeland, Espedal, \& Sirris, 2019) or because of the public ethos. We recognise these organisations as values-salient performing some kind of moral work (Billis, 2010; Hasenfeld, 2010).

Our working definition of values is as follows: Values are individual and collective trans-situational conceptions of desirable behaviours, objectives and ideals that serve to guide or valuate practice.

Our interest in values work stems from a longstanding call for bringing work back into organisations (Barley \& Kunda, 2001). Acknowledging the role of values in several institutional perspectives, we relate values to the work and agency of leaders as well as to various groups of organisational actors. Work refers to activities involving mental or physical effort performed to accomplish the results of any description. Since values are inherently connected to actions in a threefold manner-by intention, direction and interpretation - the work practices of leaders are fertile areas for studying values. We follow a recent stream of organisational research: theorising values work in organisations as ongoing performances situated in everyday practice (Gehman, Trevino, \& Garud, 2013; Vaccaro \& Palazzo, 2015). 
Values work reflects normative assumptions and goals-it concerns what is of value and what are the important behaviours to the organisation. The process of producing value-related actions is central. Values work can take place in the implementation of institutionalised practice, but it is more prominent in phases where organisations maintain, for example, their normative or value-based roots (Lawrence \& Suddaby, 2006, pp. 222-230). In this book, we define values work as including any set of acts in everyday work as being value-driven, and values work to be a particular set of actions that enhance the ongoing knowledge and reflection-creating processes that infuse an organization with value-related actions (Espedal, 2019).

\section{Values in Organisations and Leadership}

We note a resurgence of interest in values, both in public policy discourses and in research on organisational institutionalism and leadership. However, in the context of organisations, values are often taken for granted. The term or concept itself is rarely examined or discussed, despite its relevance to the purpose and direction of organisational and leadership practice. As such, this book presents studies in which values are externalised in work and become part of the social practice of leaders and organisations.

Many leadership theories have been developed to help leaders cope with challenging organisational situations. Performance management has proposed an approach to increase the effectiveness of companies by improving the performance of its employees (Armstrong \& Baron, 1998). A functionalistic guide to improving the culture through valuesbased processes (McSween, 2003) has been proposed, which identifies values as drivers of co-operation. Such 'value management' approaches have been presented to facilitate the building of values-driven organisations. Thus, work often performed by consultants has fuelled assumptions that values somehow exist in organisations independent of action and primarily constructed by leaders (Barrett, 2006). Thus, though many organisations have established core values to influence practice (Falkenberg, 2006), they are treated as 'mantras' in organisations 
(Lencioni, 2002), and organisations tend to focus more on defining them than implementing them (Gehman et al., 2013).

The last decade has seen a renewed emphasis on the importance of values ethics and morality among leaders (Copeland, 2014). Values are also related to social corporate responsibility and business ethics (Stackman, Pinder, \& Connor, 2000). Theories such as transformational leadership, authentic leadership and ethical leadership have incorporated an ethical and moral component into leader behaviour. However, in this book, we lean towards a values-based tradition that highlights values as central to understanding social processes in organisations and leadership (Selznick, 2008). Alternatively, we consider values as embedded in national cultures, shaping the charismatic idea of values-based leadership (House, 1996; House, Quigley, \& de Luque, 2010). During the last decades, contributions from a Scandinavian context have shed light on 'values-based leadership', underscoring how leaders reflect and promote processes to enhance values-consciousness in organisational practices (Aadland \& Askeland, 2017; Petersen \& Stuhr Lassen, 1997; Pruzan, 2004). What values are, what they do and what threatens them offer insights into the development of humanist concerns and viewpoints. Following Selznick (2008), values are understood as expressions of what matters in social life, what leads to social flourishing and conditions that allow for humans to thrive.

\section{Overview of Chapters in the Book}

To introduce the content of the book, we have grouped the chapters under the headings of the what, who and how of understanding values work in organisations and leadership. The what section presents a theoretical framework for understanding values, the emerging field of values work and values work in plural institutional environments. The who of values work focuses on actors, leaders and various aspects of institutional leadership. We present studies investigating institutional leadership as it creates, change and maintain institutions by practice.

The third section introduces studies elaborating how values work can be found in the processes of organisations and in situations where actors 
influence values work. What work promotes the standards, ideals and identity of organisations?

\section{The What of Understanding Values Work-A Theoretical Framework}

This section of the book takes a closer look at the values construct evident in everyday language, public debate and policy. Providing a frame for examining values work, the chapters clarify how we conceptualise and apply the term values. Askeland outlines the trajectory of values, particularly within streams of organisational institutionalism. Conveying a frame for discussing values work, it clarifies how to conceptualise the term values. Discussing classic and recent contributions, the chapter proposes a working definition of values. We review studies on values work in organisations. Espedal reviews the existing empirical studies and emerging literature on values work in organisations, aiming to disambiguate the phenomenon. Understanding values work as ongoing value performances, it is identified as social and institutional processes of constructing agency, actions and practice. Values work is part of both a performative tradition of process studies and an institutional work tradition that strives to change, disrupt and maintain institutions. The final chapter in this section, by Sirris, introduces readers to the unique complexity of the Scandinavian welfare mix by investigating how institutional complexity relates to values work in organisations. Seen complexity as a contextual condition that triggers work on values and identities, it discusses how the intersection of a welfare logic and a market logic affects organisational values and identities.

\section{Exploring Who Is Doing Values Work-The Actors}

We witness a resurgence of interest in institutional leadership, originally conceptualised by Selznick over sixty years ago (Selznick, 1957/1983). Central to the concept of institutional leadership is its distinction from 
terms such as 'management' or 'administration' (Raffaelli \& Glynn, 2015; Selznick, 1957/1983). According to Selznick, institutional leadership involves 'infusing' the organisation with values, and it distinguishes a leader from an administrator. Institutional leadership concerns establishing and protecting institutional values and character. It is oriented towards self-maintenance retrospective. While some contributions seek to identify the central aspects of institutional leadership, others show how leaders contribute to either institutional creation (Struminska-Kutra, 2018), maintenance through adaption (Askeland, 2014) or change (Kraatz \& Moore, 2002). This section foregrounds leadership in understanding how organisational values work contributes to renewal in practice. The chapters in this section address how managers work intentionally with values through different forms of institutional work.

To understand institutional leadership, we also identify how, for instance, poverty became a fundamental value of the Jesuit organisation revisiting the relevance of values. Bento da Silva discusses a less known part of Selznick's work in which the ambiguous character of values is highlighted. He analyses how poverty has been conceptualised within a Catholic religious organisation, showing that, in the Jesuit case, poverty is not strictly defined. Instead, poverty results from the constant dialogue between the individual Jesuit and their leader. Being the result of such a constant dialogue between the leader and their followers, institutional leadership can be revisited and freed from the heroic view that has long characterised it.

Askeland addresses how managers through values work enact critical functions of institutional leadership, by ongoing efforts and the recurring facilitation of processes relating the mission, values and character of the organisation. The chapter analyses how leaders maintain and develop the 'good organisation' through three thematic frames: Conceiving of the 'good home', enhancing 'the common good' and establishing a shared, embodied understanding of 'good practice'. Struminska-Kutra and Askeland illustrate how leaders respond to external pressures for change and actively transform organisational practices and identities. They argue that leader's action displays either through projective, future-oriented agency or by habitual agency. The chapter develops a typology of strategies used 
by leaders in response to plural isomorphic pressures. Lindheim explores how employees and managers negotiate leadership across cultures when interacting with one another's implicit ideas of leadership. The chapter explains how contextual factors at the institutional, field and organisational levels along with individual experiences from the native country and the Norwegian work context present a dynamic cultural configuration that shapes the implicit ideas of good and bad leadership. Vea, Kessel and Kanywenge explore how the leadership journey is experienced differently by women around the world. Analysing stories of women leaders from South Kivu, the Democratic Republic of Congo, the chapter contributes to the knowledge on how women compete and negotiate paths to leadership through values work in a context of conflict and violence.

\section{Understanding How to Do Values Work}

Our ideals are tied to our experience, choices, projects and customs. Our realisation of them is supported by sound knowledge and enhanced by how we think and our judgements of what to do. Everything worth knowing has an eidos-a form of an idea-that gives it a unique conception (Selznick, 2008). The ideas of values such as justice, piety, love and trust are normative as well as cognitive. How these values manifest in actions is an aspect that needs further investigation. A process-based perspective might aid in catching values in flight. Espedal focuses on the use of process studies in relation to the investigation of values work in organisations. The chapter explains how values work can be studied through a strong-process perspective linked to practices that develop, grow or terminate values over time. Process studies identify various mechanisms and issues related to the performative, situated and agentic nature of values work. In this work, different methodology approaches are suggested for process studies investigating values work and institutionalising processes.

Von Essen analyses how values related to the volunteer experience are used to construct identities of engaged citizens in contemporary Swedish society. By evaluating a normative significant situation, a human agent discloses the kind of person she wants to be, so that identity is defined by the agent's evaluations. Kivle elaborates on mechanisms of values work, 
based on textual analysis concerning trust and trust-based management in three Scandinavian popular scientific journals. Findings indicate that trust is 'worked upon' simultaneously within competing frameworks, which are also interpreted to be manifestations of differences between institutional logics.

Løvaas and Vråle investigate how values work are performed through group reflections of middle managers. Findings indicate that spaces of group reflection enable individual actors to move inward representing identity processes, and move forward, getting the courage and strength from the managerial group reflection. Sirris explores how managers negotiate organisational core values to perform values work. The chapter conceptualises the dynamics of values being simultaneously fixed-at an organisational discursive level—and fluid—at an individual managerial level_as value elasticity.

We believe these studies allow a more nuanced understanding of values work in organisations and divergent configurations of practice. We argue this promotes better consciousness and reflection on standards and ideals in difficult organisational situations. The editors and authors of this book sincerely hope that this work will stimulate further discussions and dialogue on how to perform values work in organisations. We also hope that it serves as a useful resource for scholars working in the domains of organisation and leadership studies.

The editors want to express our gratitude to those who gave their help in the process of writing and production of this volume. Professor Arild Wæraas, professor Annette Leis-Peters and Ph.D. fellow Bjørg Aambø Østby have all given invaluable comments to early drafts of the individual chapters. We are also thankful to Liz Barlow at Palgrave for believing in and accepting this book, along with generous support from our own institution, VID, by rector Ingunn Moser and vice-rector Bård Mæland to fund the open-access publication. 


\section{References}

Aadland, E., \& Askeland, H. (2017). Verdibevisst ledelse [Valueconscious leadership]. Oslo, Norway: Cappelen Damm.

Armstrong, M., \& Baron, A. (1998). Performance management: The new realities. Ithaca, NY: Cornell University.

Askeland, H. (2014). Leaders should be the carriers of institutional values: An account of how leaders contribute to the value-base of diaconal institutions. Diaconia: Journal for the Study of Christian Social Practice, 5(2), 147-175.

Askeland, H., Espedal, G., \& Sirris, S. (2019). Values as vessels of religion? Role of values in everyday work at faith-based organisations. Diaconia: Journal of the Study of Christian Social Practice, 10(1), 27-49.

Barley, S. R., \& Kunda, G. (2001). Bringing work back in. Organization Science, 12(1), 76-95.

Barrett, R. (2006). Building a values-driven organization: A whole system approach to cultural transformation. London, UK: Routledge.

Billis, D. (2010). Hybrid organizations and the third sector: Challenges for practice, theory and policy. New York, NY: Palgrave Macmillan.

Copeland, M. K. (2014). The emerging significance of values based leadership: A literature review. International Journal of Leadership Studies, 8(2), 105135.

Espedal, G. (2019). Being compassionate. Institutionalizing through values work in a faith-based organization (PhD). VID Specialized University, Oslo.

Falkenberg, G. (2006). Verdier og sosiale normer $i$ store norske virksomheter. Viktige kulturbarere eller fordekt PR? [Values and social norms in large Norwegian companies: Important cultural carrieres or hidden PR]. Retrieved from https://www.fafo.no/media/com_netsukii/10028.pdf.

Gehman, J., Trevino, L. K., \& Garud, R. (2013). Values work: A process study of the emergence and performance of organizational values practices. Academy of Management Journal, 56(1), 84-112.

Greenwood, R., Raynard, M., Kodeih, F., Micelotta, E. R., \& Lounsbury, M. (2011). Institutional complexity and organizational responses. The Academy of Management Annals, 5(1), 317-371.

Hampel, C. E., Lawrence, T. B., Tracey, P., Greenwood, R., \& Oliver, C. (2017). Institutional work: Taking stock and making it matter. In R. Greenwood, C. Oliver, T. B. Lawrence, \& R. Meyer (Eds.), The Sage handbook of organizational institutionalism (pp. 558-590). London, UK: Sage. 
Hasenfeld, Y. (1983). Human service organizations. Englewood Cliffs, NJ: Prentice Hall.

Hasenfeld, Y. (2010). The attributes of human service organizations. In Y. Hasenfeld (Ed.), Human services as complex organizations (2nd ed., pp. 932). Thousand Oaks, CA: Sage.

House, R. J. (1996). Path-goal theory of leadership: Lessons, legacy and a reformulated theory. Leadership Quarterly, 7(3), 323-352.

House, R. J., Quigley, N. R., \& de Luque, M. S. (2010). Insights from Project GLOBE: Extending global advertising research through a contemporary framework. International Journal of Advertising, 29(1), 111-139.

Kraatz, M. S., \& Block, E. S. (2008). Organizational implications of institutional pluralism. In R. Greenwood, C. Oliver, K. Sahlin, \& R. Suddaby (Eds.), The Sage handbook of organizational institutionalism (pp. 243-276). Thousand Oaks, CA: Sage.

Kraatz, M. S., \& Moore, J. H. (2002). Executive migration and institutional change. Academy of Management Journal, 45(1), 120-143.

Lawrence, T. B., \& Suddaby, R. (2006). Institutions and institutional work. In S. R. Clegg, C. Hardy, T. B. Lawrence, \& W. R. Nord (Eds.), The Sage handbook of organization studies (2nd ed., pp. 215-254). London, UK: Sage.

Lencioni, P. M. (2002). Make your values mean something. Harvard Business Review, 80(7), 113-117.

McSween, T. E. (2003). Values-based safety process: Improving your safety culture with behavior-based safety. Hoboken, NJ: Wiley.

Micelotta, E., Lounsbury, M., \& Greenwood, R. (2017). Pathways of institutional change: An integrative review and research agenda. Journal of Management, 43(6), 1885-1910.

Petersen, V. C., \& Stuhr Lassen, M. (1997). Verdibaseret ledelse: et alternativ til styring, regulering og kontrol? [Valuebased leadership: An alternative to governance, regulation and control?]. København, Denmark: Dansk Industri.

Pruzan, M Ma P. (2004). Values-based leadership. In L. Zsolnai (Ed.), Ethics in the economy: Handbook of business ethics. Oxford, UK: Peter Lang.

Raffaelli, R., \& Glynn, A. (2015). What's so institutional about leadership? Leadership mechanisms of value infusion. In M. S. Kraatz (Ed.), Institutions and ideals: Philip Selznick's legacy for organizational studies (Vol. 44). Bingley, UK: Emerald.

Selznick, P. (1957/1983). Leadership in administration: A sociological interpretation. Berkeley: University of California Press.

Selznick, P. (2008). A humanist science: Values and ideals in social inquiry. Stanford, CA: Stanford University Press. 
Stackman, R. W., Pinder, C. C., \& Connor, P. E. (2000). Values lost: Redirecting research on values in the workplace. In N. M. Ashkanasy, C. P. M. Wilderom, \& M. F. Peterson (Eds.), Handbook of organizational culture and climate (pp. 37-54). Thousand Oaks, CA: Sage.

Struminska-Kutra, M. (2018). Democratizing public management: Towards practice-based theory. Cham, Switzerland: Palgrave Macmillan.

Vaccaro, A., \& Palazzo, G. (2015). Values against violence: Institutional change in societies dominated by organized crime. Academy of Management Journal, 58(4), 1075-1101.

Open Access This chapter is licensed under the terms of the Creative Commons Attribution 4.0 International License (http://creativecommons.org/ licenses/by/4.0/), which permits use, sharing, adaptation, distribution and reproduction in any medium or format, as long as you give appropriate credit to the original author(s) and the source, provide a link to the Creative Commons license and indicate if changes were made.

The images or other third party material in this chapter are included in the chapter's Creative Commons license, unless indicated otherwise in a credit line to the material. If material is not included in the chapter's Creative Commons license and your intended use is not permitted by statutory regulation or exceeds the permitted use, you will need to obtain permission directly from the copyright holder. 